\title{
Adiponectin Inhibits Spontaneous and Catecholamine-Induced Lipolysis in Human Adipocytes of Non-Obese Subjects Through AMPK-Dependent Mechanisms
}

\author{
Z. WEDELLOVÁ ${ }^{1,4}$, J. DIETRICH ${ }^{6}$, M. ŠIKLOVÁ-VÍTKOVÁ ${ }^{1}$, K. KOLOŠTOVÁ ${ }^{2}$, \\ M. KOVÁČIKOVÁ ${ }^{1,3}$, M. DUŠKOVÁ ${ }^{5}$, J. BROŽ $^{4}$, T. VEDRAL ${ }^{7}$, V. ŠTICH ${ }^{1,3,4}$, J. POLÁK $^{1,4,8}$ \\ ${ }^{1}$ Department of Sport Medicine, Third Faculty of Medicine, Charles University in Prague, Czech \\ Republic, ${ }^{2}$ Center of Biomedical Sciences, Division of Cell and Molecular Biology, Third Faculty \\ of Medicine, Charles University in Prague, Czech Republic, ${ }^{3}$ Franco-Czech Laboratory for Clinical \\ Research on Obesity, Third Faculty of Medicine and INSERM Unite 586, Charles University, \\ Prague, Czech Republic, ${ }^{4}$ Second Internal Medicine Department, University Hospital of Kralovske \\ Vinohrady, Prague, Czech Republic, ${ }^{5}$ Plastic Surgery Department, University Hospital of Kralovske \\ Vinohrady, Prague, Czech Republic, ${ }^{6}$ University of Applied Sciences Wildau, Germany, ${ }^{7}$ General \\ Surgery Department, University Hospital of Kralovske Vinohrady, Prague, Czech Republic, ${ }^{8}$ Center \\ for Research of Diabetes, Metabolism and Nutrition, Third Faculty of Medicine, Charles University \\ in Prague, Czech Republic
}

Received July 20, 2009

Accepted May 26, 2010

On-line October 15, 2010

\begin{abstract}
Summary
Adiponectin is an adipokine increasing glucose and fatty acid metabolism and improving insulin sensitivity. The aim of this study was to investigate the role of adiponectin in the regulation of adipocyte lipolysis. Human adipocytes isolated from biopsies obtained during surgical operations from 16 non-obese and 17 obese subjects were incubated with 1) human adiponectin $(20 \mu \mathrm{g} / \mathrm{ml})$ or 2) $0.5 \mathrm{mM}$ AICAR - activator of AMPK (adenosine monophosphate activated protein kinase). Following these incubations, isoprenaline was added $\left(10^{-6} \mathrm{M}\right)$ to investigate the influence of adiponectin and AICAR on catecholamine-induced lipolysis. Glycerol concentration was measured as lipolysis marker. We observed that adiponectin suppressed spontaneous lipolysis by $21 \%$ and isoprenaline-induced lipolysis by $14 \%$ in non-obese subjects. These effects were not detectable in obese individuals, but statistically significant differences in the effect of adiponectin between obese and non-obese were not revealed by two way ANOVA test. The inhibitory effect of AICAR and adiponectin on lipolysis was reversed by Compound $C$. Our results suggest, that adiponectin in physiological concentrations inhibits spontaneous as well as catecholamine-induced lipolysis. This effect might be lower in obese individuals and this regulation seems to involve AMPK.
\end{abstract}

\section{Key words}

Obesity • Adiponectin • Lipolysis • Adipose tissue • AMPK

\section{Corresponding author}

Jan Polak, Third Faculty of Medicine of Charles University, Sport Medicine Department, Center of Preventive Medicine, Ruská 87, 10000 Prague 10, Czech Republic. Fax: +420 267102263. E-mail: jan.polak@lf3.cuni.cz

\section{Introduction}

Obesity characterized by excessive lipid accumulation in adipose tissue as well as in ectopic localizations (especially muscle and liver) was shown to increase the risk of developing insulin resistance, type 2 diabetes mellitus, hypertension, cardiovascular diseases, several types of cancer and other chronic diseases (Hayes et al. 2008). Among the major mediators possibly contributing to a development of insulin resistance, pancreatic endocrine dysfunction, atherosclerosis and whole body pro-inflammatory state belong the excessive flux of non-esterified fatty acids (NEFA) from adipose 
tissue and a family of proteins produced in adipose tissue, collectively named adipokines (Boden et al. 2008).

Non-esterified fatty acids represent primary energy source for metabolically active tissues, including skeletal muscle (Bickerton et al. 2007), however increasing amount of evidence suggests, that the excessive flux of NEFA from adipose tissue of obese individuals (Baldeweg et al. 2000) is an important factor in the etiopathogenesis of obesity-related metabolic impairments, mainly insulin resistance (Frayn et al. 2001). Insulin resistance-inducing effect of NEFA in muscle has been firstly conceptualized by Randle (Randle et al. 1998) who noticed the substrate competition between fatty acids and glucose in myocytes. This concept was further investigated and mechanisms of NEFA-induced impairments of insulin signaling were described at the molecular level in muscle as well as liver. Furthermore, NEFA play an important role also in this process of endocrine pancreatic dysfunction, which represents the second step in the development of type 2 diabetes, and contribute thus to diminished insulin output from pancreas in response to glucose stimulus (Yaney et al. 2000).

Adipose tissue lipolysis is regulated by a complex interaction between lipolytic and anti-lipolytic hormones. Under physiological circumstances, catecholamines and atrial natriuretic peptide (ANP) are the most important lipolysis stimulating factors (Lafontan et al. 2008), while insulin is a potent anti-lipolytic agent. During fasting, stress and exercise is lipolysis stimulated by growth hormone to spare glucose and proteins at the expense of lipids (Moller et al. 2009). Obese individuals have been shown to suffer from several dysregulations in lipolysis regulation, including increased rate of spontaneous lipolysis in subcutaneous adipose tissue in vitro as well as in vivo (Arner et al. 2005) and decreased stimulation of lipolysis during exercise or following local in-situ catecholamine administration, compared to healthy subjects, partially due to enhanced anti-lipolytic effect mediated through $\alpha_{2}$-adrenergic receptors (Stich $e t$ al. 2003). Obesity is associated with suppressed levels of circulating growth hormone compared with normalweight subjects (Veldhuis et al. 1991, Laessle et al. 1997), what may contribute to maintenance of obesity, because fat deposits are maintained (Laessle et al. 1997). Recently, the role of adipokines in lipolysis regulation has been investigated and the strong lipolytic effect of tumor necrosis factor- $\alpha$ (TNF- $\alpha$ ) and interleukin-6 (IL-6) was established together with their physiological role in pro-inflammatory state induction (TNF- $\alpha$ ) and substrate flux regulation during exercise (IL-6) (Cawthorn et al. 2008). Adiponectin is a unique adipokine produced in mature adipocytes with profound insulin-sensitising, antiinflammatory and anti-atherosclerotic effects (Yamauchi et al. 2002, Haluzik et al. 2004, Nedvidkova et al. 2005). Adiponectin increases glucose uptake and fatty acid oxidation in muscle and reduces hepatic gluconeogenesis (Yamauchi et al. 2002). Its cellular effects in muscle and liver are at least partially mediated by the activation of 5'-AMP-activated protein kinase (AMPK) (Yamauchi et al. 2002). Adiponectin receptors are ubiquitously expressed on several human tissues including muscle, liver, pancreas and adipocytes (Yamauchi et al. 2003). However, the paracrine/endocrine role of adiponectin on adipocytes has never been thoroughly investigated. Available literature identified AMPK as a key regulator of cellular energy metabolism including regulation of lipogenesis, $\beta$-oxidation and lipolysis (Daval et al. 2006). We hypothesized that adiponectin stimulates AMPK also in human adipocytes and participates in the regulation of lipolysis at the tissue level by paracrine and (via systemic circulation) also endocrine mechanisms.

The main aim of this study was to investigate the in-vitro effect of adiponectin at physiological concentrations on the spontaneous and catecholaminestimulated lipolysis using isolated adipocytes from subcutaneous adipose tissue. Subsequently we investigated whether lipolytic response of adipocytes from obese and non-obese individuals is different following adiponectin administration.

\section{Methods}

\section{Subjects}

The samples of adipose tissue were obtained during planned laparoscopic operations (cholecystectomy, hernioplastics) or plastic surgery (liposuction). The samples of tissue were taken by the surgeons during laparoscopy surgery under direct vision from the abdominal adipose tissue located immediately under the skin, at the beginning of the surgery. During liposuction the tissue had been taken at the beginning of the surgery as well, before the tissue was infiltrated by adrenaline, to avoid the contamination of the tissue by any pharmaceuticals. All samples were taken from the abdominal area. No sample of adipose tissue in this study had been taken by transcutaneous biopsy. The samples of adipose tissue were given to a saline solution and immediately transported to the laboratory for 
experiments. The adipose tissue was obtained from 17 obese women $\left(\mathrm{BMI}=37.6 \pm 5.6 \mathrm{~kg} / \mathrm{m}^{2}\right.$, age $=41.9 \pm 10.9$ years) and 16 non-obese subjects (4 men, 12 women, $\mathrm{BMI}=23.6 \pm 2.2 \mathrm{~kg} / \mathrm{m}^{2}$, age $=45.4 \pm 15.9$ years $)$. Before including the patients to the study we were informed about their concomitant diseases and only patients without any acute or chronic disease except of obesity were included to the study and the sample of adipose tissue had been taken during the surgery. However, in the group of non-obese patients two of them were on thyroid substitution. The hypothyreosis was in both cases stationary, so we do not suppose any effect on the metabolism of adipocytes.

For the additional experiment (Indirect evidence of AMPK activation using Compound $C$, see below) we used the adipose tissue obtained from 3 human non-obese subjects (females, BMI $23.4^{ \pm} 2.0 \mathrm{~kg} / \mathrm{m}^{2}$ ). All participants gave written informed consent before starting the study. All aspects of the study were performed in accordance with the Declaration of Helsinki and were approved by the Ethical committee of the Third Faculty of Medicine, Charles University (Prague, Czech Republic).

\section{Adipocyte isolation}

Immediately after the biopsy was taken, the tissue was transported to the laboratory for experiments. Isolated adipocytes were obtained as previously described by Rodbell (Rodbell M 1964). Briefly, the whole tissue was cut into small pieces and subsequently digested by $1.25 \mathrm{mg} / \mathrm{ml}$ collagenase (Sigma Collagenase from Clostridium histolyticum, Prod. No. C6885) in Krebs Ringer Bicarbonate buffer containing $10 \mathrm{mmol} / \mathrm{l}$ Hepes, $2 \%$ fatty acid free bovine serum albumin (KRBHA) and $6 \mathrm{mmol} / \mathrm{l}$ glucose at $\mathrm{pH}$ 7.4, under shaking at 100 cycles/min at $37^{\circ} \mathrm{C}$ during $30 \mathrm{~min}$. Adipocytes were filtered through a silk screen $(250 \mu \mathrm{m})$ and washed 3 times with KRBHA buffer to eliminate collagenase.

\section{In-vitro incubation and lipolysis determination}

The freshly isolated fat cells were divided in 4 batches, each containing $95 \mu 1$ of cell suspension and 80 $\mu \mathrm{l}$ of KRBHA buffer. Cells in each batch were left resting for one hour prior to following experiments to enable cells recover after collagenase digestion and manipulation. Four different incubations were performed in parallel with cells obtained from each subject: the first batch (control) was than incubated for 4 hours without any pharmacological intervention, second batch was incubated without pharmacological substances for first 2 hours and subsequently isoprenaline was added at the final concentration of $10^{-6} \mathrm{~mol} / \mathrm{l}$ for last 2 hours, third batch was incubated with the final concentration of $20 \mu \mathrm{g} / \mathrm{ml}$ of adiponectin for 2 hours and subsequently with isoprenaline $\left(10^{-6} \mathrm{M}\right)$, fourth batch was incubated for 2 hours in the final concentration of $0.5 \mathrm{mmol} / 1 \mathrm{AICAR}$ (aminoimidazole carboxamide ribonucleotide, activator of AMPK) and subsequently with isoprenaline $\left(10^{-6} \mathrm{M}\right)$ for last 2 hours. Glycerol was determined by colorimetric assay (Glycerol kit, Randox laboratories, Crumin, United Kingdom) in cultivation media after one hour of rest and subsequently following 2 hours of incubation with adiponectin or AICAR and finally, after 2-hour incubation with isoprenaline in all the batches. Following the incubations, total lipid content in each tube was extracted with heptane and isopropylalcohol and subsequently quantified using the Dole method. Values of glycerol concentration in media were expressed as per $100 \mathrm{mg}$ of lipids.

\section{Determination of AMPK involvement}

Indirect evidence of AMPK activation was evaluated using a specific cell-permeable agent named Compound C (6-[4-(2-Piperidin-1-yl-ethoxy)-phenyl)]-3pyridin-4-yl-pyrazolo[1,5-a] pyrimidine), which was shown to effectively block AMPK activation in several tissues including adipocytes (Zhou et al. 2001, Gao et al. 2008, Koh et al. 2007). For these experiments, adipose tissue of non-obese subjects was processed as described above and isolated cells were firstly pre-incubated for 2 hours with Compound $\mathrm{C}(0.5 \mathrm{mmol} / \mathrm{l})$. After this period of pre-incubation, subsequent 2-hour incubations with adiponectin $20 \mathrm{mg} / 1$ or $0.5 \mathrm{mM}$ AICAR were performed.

\section{Statistical analysis}

Statistical analysis was performed using SPSS 13.0 for Windows SPSS Inc., Chicago, IL). The effect of pharmacological substances was evaluated using paired Student's t-test. Differential effects of treatments between groups (obese versus non-obese) were tested using Twoway ANOVA analysis where treatment and obesity status were considered as independent variables in the model. Data are presented as mean values \pm SD. A level of $\mathrm{p} \leq 0.05$ was considered statistically significant in all tests.

\section{Results}

\section{Spontaneous lipolysis}

Data were expressed in absolute values of glycerol concentration in media normalized to $100 \mathrm{mg}$ of 


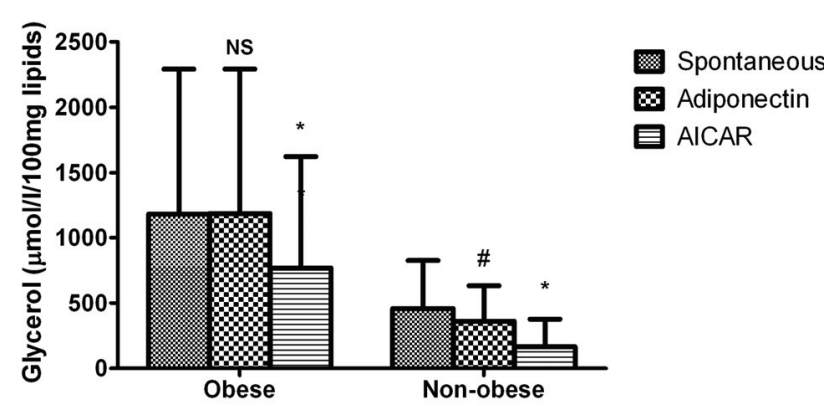

Fig. 1. Glycerol concentration in media following 2-hour incubation. Adipocytes of obese and non-obese subjects were incubated for 2 hours without any treatment (spontaneous lipolysis) or with the presence of $20 \mathrm{mg} / \mathrm{l}$ adiponectin or $0.5 \mathrm{mM}$ AICAR. Data are expressed as the mean glycerol concentration in media following the incubation period. $* p<0.05$ for comparison between spontaneous and pharmacological incubation (AICAR); $\# p=0.06$ for comparison between spontaneous and pharmacological incubation (Adiponectin)

lipids. The cumulative 2-hour glycerol concentration representing spontaneous lipolytic rate was $458.4 \pm 365.7$ $\mu \mathrm{mol} / \mathrm{l} / 100 \mathrm{mg}$ lipids in the control tube, while incubation with adiponectin led to a suppression of lipolysis by $21 \%$ $(\mathrm{p}=0.06)$ and co-incubation with AICAR suppressed lipolysis by $64 \%(\mathrm{p}=0.005)$, in non-obese individuals. Spontaneous lipolysis was 2.6 times higher in obese individuals $(\mathrm{p}=0.02)$. Incubation with AICAR inhibited spontaneous lipolysis by $35 \%(\mathrm{p}<0.001)$ in obese subjects, while the effect of adiponectin was diminished (inhibition by $2 \%, \mathrm{p}=0.43$ ). However no statistically significant differences between obese and non-obese individuals were observed for AICAR as well as adiponectin treatments, according to two-way ANOVA testing. These data are displayed in Figure 1.

\section{Catecholamine-induced lipolysis}

2-hour incubation with isoprenaline stimulated lipolysis 4.4 times in non-obese and 2.4 times obese individuals (both $\mathrm{p}<0.05$ ). Adiponectin inhibited isoprenaline-induced lipolysis in non-obese by $14 \%$ $(\mathrm{p}=0.03)$, while AICAR inhibited isoprenaline-induced stimulation of lipolysis by $71 \%$ and $35 \%$ in non-obese and obese subjects ( $\mathrm{p}=0.006$ and $\mathrm{p}=0.04$, resp.). Despite lower inhibitory effect of adiponectin in obese individuals, no statistical differences were observed between obese and non-obese individuals for AICAR as well as adiponectin treatments, according to two-way ANOVA test. Data are summarized in Figure 2.

\section{AMPK inactivation by Compound C}

In additional experiment cells were incubated for 2 hours separately with AICAR or adiponectin and in

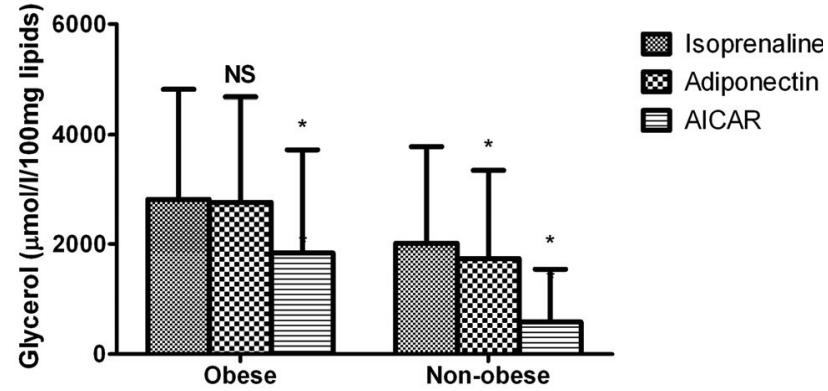

Fig. 2. Isoprenaline-induced lipolysis following 2-hour incubation. Adipocytes of obese and non-obese subjects were incubated for 2 hours with $10^{-6} \mathrm{M}$ isoprenaline without any other treatment (Isoprenaline) and with the presence of $20 \mathrm{mg} / \mathrm{l}$ adiponectin or $0.5 \mathrm{mM}$ AICAR. Data are expressed as the relative change of mean glycerol concentration in media during the incubation period. * $\mathrm{p}<0.05$ for comparison between spontaneous and pharmacological incubation (Adiponectin or AICAR)

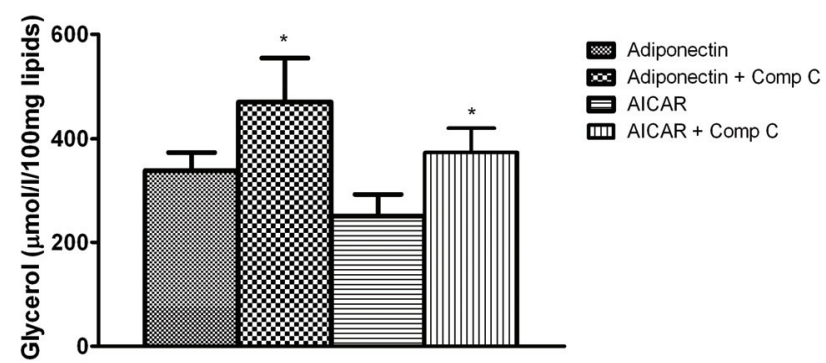

Fig. 3. Glycerol concentration after 4-hour co-incubation of adiponectin or AICAR with Compound C. Adipocytes of non-obese subjects were incubated with $20 \mathrm{mg} / \mathrm{l}$ adiponectin or $0.5 \mathrm{mM}$ AICAR in the presence or absence of $0.5 \mathrm{mM}$ Compound $\mathrm{C}$ (inhibitor of AMPK). Data are expressed as the mean glycerol concentration in media following the incubation period. * $p<0.01$ for comparison between spontaneous and pharmacological incubation (Adiponectin or AICAR)

parallel with addition of AMPK inactivator (Compound C). Anti-lipolytic effect of both, AICAR as well as adiponectin was reversed by Compound C. Addition of Compound $\mathrm{C}$ increased lipolysis by $37.8 \%(\mathrm{p}<0.001)$ when co-incubated with adiponectin and by $49.5 \%$ $(\mathrm{p}<0.001)$ following the co-incubation with AICAR. Data are summarized in Figure 3.

\section{Discussion}

This study investigates for the first time the role of adiponectin in the regulation of lipolysis in human adipocytes. The major finding is that adiponectin moderately inhibits spontaneous as well as catecholamine-induced lipolysis in non-obese individuals, while this effect seems to be diminished in obese subjects. Furthermore, we suggest, that AMPK is involved in the effect of adiponectin on lipolysis in 
human adipocytes.

Adiponectin was shown to activate AMP-kinase in human liver and muscle by specific phosphorylation of Thr-172 residue through yet not fully clarified mechanisms. After binding of adiponectin to membrane receptors (AdipoR1, AdipoR2) that were also identified in human adipose tissue (Tan et al. 2006), activation of APPL1 (Adaptor protein with plecthrin homology) was described in liver, muscle and adipocytes (rat) (Saito et al. 2007, Deepa et al. 2009, Mao et al. 2006) with subsequent involvement of several signaling cascades, including PPAR $\alpha$, MAPK and AMP-kinase pathway (Kadowaki et al. 2006). However, it remains unclear, whether APPL1 is mediating adiponectin-induced effects in human adipose tissue as well. Activated AMP-kinase subsequently phosphorylates hormone sensitive lipase (HSL), a key regulator of adipocyte lipolysis, at the Ser565 position, also referred as "Site-2" (Garton et al. 1990, Garton et al. 1989). Phosphorylation at this position was shown to prevent HSL phosphorylation at Ser-563 position, also referred as "Site-1" (Carmen et al. 2006, Holm et al. 2003), which is a common substrate for cAMP-dependent lipolysis-activating pathways (e.g. $\beta$-adrenergic stimulation) and leads to HSL activation and lipid hydrolysis (Langin et al. 2005, Arner et al. 1990). AMPK activation thus inhibits/prevents HSL activation. Additional possible mechanism explaining adiponectin anti-lipolytic effect might represent interaction between adiponectin signaling and insulin signaling pathways. It has been shown, that APPL1 interacts with key parts of the insulin-signaling pathway in adipocytes (as well as myocytes and endothelial cells) (Deepa et al. 2009), especially PI3K and Akt/PKB (Yang et al. 2003), and is essential for insulin-mediated metabolic effects in adipocytes (including Akt phosphorylation, glucose uptake, GLUT 4 translocation) (Saito et al. 2007, Mitsuuchi et al. 1999). It can be hypothesized, that adiponectin-induced activation of APPL1 in human adipocytes leads to subsequent activation of Akt and to anti-lipolytic effect through well described mechanisms identical to insulin-mediated anti-lipolytic cascade.

Our finding that stimulation of AMPK by AICAR and to a smaller extent by adiponectin in our study inhibits spontaneous as well as catecholamineinduced lipolysis in lean subjects is congruent with the evidence obtained mainly in animal models and suggests that this regulation is present also in human adipocytes. Furthermore, we showed that the anti-lipolytic effect of adiponectin can be reversed by Compound $\mathrm{C}$, a potent
AMPK inactivator, suggesting that AMPK activation plays a role in adiponectin signaling in adipose tissue, which is in line with previously published study showing that Compound C blocks AMPK in hepatocytes (Zhou et al. 2001).

The present study supports the concept of adiponectin paracrine effects in adipose tissue. Subcutaneous abdominal, femoral and visceral adipose tissues have different expression of adiponectin gene and possibly also protein production. As plasma levels of adiponectin are rather high, a true endocrine effect can be suggested as well. Adiponectin might serve as a messenger regulating lipolysis between different adipose tissue depots. Additionally, other tissues, especially skeletal muscle and liver, were shown to posses the ability of lipolysis, mediated through similar mechanisms as in adipose tissue (including the activation of HSL) (Qvisth et al. 2006, Jocken et al. 2008). It can be thus speculated, that adiponectin might serve as inter-organ regulator of lipolysis, influencing also lipid degradation localized in muscle and liver. Whether this regulation has some physiological relevance needs to be investigated in future studies.

Based on recent literature showing that effects of adiponectin in muscle are diminished in obesity (Bruce $e t$ al. 2005, Mullen et al. 2009), we hypothesized that adiponectin might inhibit lipolysis in adipose tissue of lean subjects, while adipose tissue of obese individuals might be "adiponectin resistant" and thus the effect of adiponectin decreased or absent. Adiponectin resistance in adipose tissue, together with decreased levels of adiponectin in obese individuals and insulin resistance of adipocytes (Arner et al. 2005, Large et al. 1998), might subsequently contribute to elevated plasma levels NEFA (non-esterified fatty acids) in obese individuals. Higher NEFA participate in the induction of the insulin resistance, pancreatic dysfunction and related metabolic disturbances (Yaney et al. 2000, Paolisso et al. 1995, Chen et al. 1999, Diaz-Guerra et al. 1991). Unfortunately, based on our data, we cannot unequivocally confirm this hypothesis. We observed suppression of spontaneous and catecholamine-induced lipolysis in lean subjects and absent effect of adiponectin in obese individuals when this effect was tested in each group separately; however, two-way ANOVA test failed to show significant differences in response to adiponectin treatment between both groups. This lack of significance is due to large inter-individual variability of both spontaneous as well as catecholamine-induced lipolysis 
in human isolated adipocytes.

Interestingly, we observed that the effect of AICAR on lipolysis is preserved in obese as well as nonobese individuals. This observation is in agreement with previously published findings in skeletal muscle (Steinberg et al. 2004, Hojlund et al. 2004), and suggests that potentially insufficient suppression of lipolysis by adiponectin in obese individuals might be due to defect localized upstream of AMPK. Both, receptor and postreceptor processes can be involved. Indeed, the expression of AdipoR1 and AdipoR2 in myocytes was found to be negatively influenced by obesity and elevated insulin levels in humans as well as animal models (Tsuchida et al. 2004, Civitarese et al. 2004), however these findings were not uniformly replicated and other authors claim that triglycerides, growth hormone or firstphase insulin secretion are more important determinants of adiponectin receptors expression (Fasshauer et al. 2004, Staiger et al. 2004). Additionally, impaired ability of adiponectin to simulate AMPK was found in muscle of obese and type 2 diabetic subjects by mechanisms independent of adiponectin receptors, suggesting a postreceptor defect (Chen et al. 2005).

Our study has several limitations that need to be taken into account. First, we have not explicitly (using two-way ANOVA) shown that the effect of adiponectin is different between obese and lean subjects. Our hypothesis, that adipocytes from obese subjects are resistant to the effect of adiponectin is based on simple paired comparisons in each group separately and thus need to be interpreted as preliminary and with caution. Future studies are needed to definitely clear this issue. Second, there exists an inherent limitation to the interpretation of this study resulting from the in-vitro nature of experiments and the use of AICAR for AMPK activation. Despite the use of AICAR for in-vivo as well as in-vitro experiments, it needs to be noted, that AICAR does not have exclusive specificity to AMPK and subsequently, activation of other enzymes dependent on cAMP appears in parallel. However, specific activators of AMPK are not available so far and the above mentioned limitation could be probably solved by transgenic animal models and/or gene expression manipulations in other studies. Third, we used samples of subcutaneous abdominal adipose tissue from both men and women in the group of non-obese subjects. At the present time it is not fully understood if there are any differences in metabolism of adipose tissue between men and women so we do not know if using of both gender can influence our results. In the literature can be found studies considering an in-vitro lipolysis where the study groups were either homogenous: only men (Hoffstedt et al. 1997, Polak et al. 2007) or women, or men and women together (Kolehmainen et al. 2000, Van Harmelen et al. 1997). Few studies describe the gender variations in adipose tissue lipolysis. It had been described no difference in basal and catecholamine stimulated lipolysis in vitro between men and women (Mauriege et al. 1999, Lundgren et al., 2008), and no difference in gender in maximal lipolytic responses to isoprenaline (Mauriege et al. 1999), in another study is described higher basal lipolysis of isolated adipocytes in men than in women (Aguado et al. 2008). Another author presents data that catecholamine regulation of lipolysis in subcutaneous adipocytes from men tends to be higher than in women (Lundgren et al. 2008). In the future, it would be necessary to study the effect of adiponectin on lipolysis in men in comparison to women.

In conclusion, our study showed that adiponectin interacts with lipolytic regulation in human adipocytes under basal conditions as well as after catecholamine stimulation. These effects seem to be at least partially mediated by the activation of AMPK and subsequent interaction with intracellular signaling cascades. Furthermore, we provide some indirect indices suggesting, that adiponectin-mediated anti-lipolytic effect might be diminished in obese individuals. Further studies are necessary to definitely confirm presumed lower effect of adiponectin in obesity as well as to elucidate the role of adiponectin in lipolysis regulation in other tissues, especially muscle as well as the role of physical training and diet intervention on the suggested adiponectin resistance.

\section{Conflict of Interest}

There is no conflict of interest.

\section{Acknowledgements}

This study was supported by the grant of The Grant Agency of Charles University in Prague No. GAUK $1269 / 08 / \mathrm{C} / 2008$ and by The Research Project of the Czech Ministry of Education MSM 0021620814, by project HEPADIP, supported by the European Commission as Integrated Projects under the 6th Framework Programme (Contract LSHM-CT-2005018734) and by project ADAPT, supported under the seventh Framework Programme of European Union (HEALTH-F2-2008-201100). 


\section{References}

AGUADO M, MARTINEZ-URBISTONDO D, SOLOMON A, MARTINEZ JA: Gender-dependent differences in the response of human adipocytes to leptin lipolytic action. Methods Find Exp Clin Pharmacol 30: 7-11, 2008.

ARNER P: Human fat cell lipolysis: biochemistry, regulation and clinical role. Best Pract Res Clin Endocrinol Metab 19: 471-482, 2005.

ARNER P, KRIEGHOLM E, ENGFELDT P, BOLINDER J: Adrenergic regulation of lipolysis in situ at rest and during exercise. J Clin Invest 85: 893-898, 1990.

BALDEWEG SE, GOLAY A, NATALI A, BALKAU B, DEL PRATO S, COPPACK SW: Insulin resistance, lipid and fatty acid concentrations in 867 healthy Europeans. European Group for the Study of Insulin Resistance (EGIR). Eur J Clin Invest 30: 45-52, 2000.

BICKERTON AS, ROBERTS R, FIELDING BA, HODSON L, BLAAK EE, WAGENMAKERS AJ, GILBERT M, KARPE F, FRAYN KN: Preferential uptake of dietary Fatty acids in adipose tissue and muscle in the postprandial period. Diabetes 56: 168-176, 2007.

BODEN G: Obesity and free fatty acids. Endocrinol Metab Clin North Am 37: 635-636, 2008.

BRUCE CR, MERTZ VA, HEIGENHAUSER GJ, DYCK DJ: The stimulatory effect of globular adiponectin on insulin-stimulated glucose uptake and fatty acid oxidation is impaired in skeletal muscle from obese subjects. Diabetes. 54: 3154-3160, 2005.

CARMEN GY, VICTOR SM: Signalling mechanisms regulating lipolysis. Cell Signal 18: 401-408, 2006.

CAWTHORN WP, SETHI JK: TNF-alpha and adipocyte biology. FEBS Lett 582: 117-131, 2008.

CHEN MB, MCAINCH AJ, MACAULAY SL, CASTELLI LA, O'BRIEN PE, DIXON JB, CAMERON-SMITH D, KEMP BE, STEINBERG GR: Impaired activation of AMP-kinase and fatty acid oxidation by globular adiponectin in cultured human skeletal muscle of obese type 2 diabetics. J Clin Endocrinol Metab 90: 3665$3672,2005$.

CHEN X, IQBAL N, BODEN G: The effects of free fatty acids on gluconeogenesis and glycogenolysis in normal subjects. J Clin Invest 103: 365-372, 1999.

CIVITARESE AE, JENKINSON CP, RICHARDSON D, BAJAJ M, CUSI K, KASHYAP S, BERRIA R, BELFORT R, DEFRONZO RA, MANDARINO LJ, RAVUSSIN E: Adiponectin receptors gene expression and insulin sensitivity in non-diabetic Mexican Americans with or without a family history of Type 2 diabetes. Diabetologia 47: 816-820, 2004.

DAVAL M, FOUFELLE F, FERRE P: Functions of AMP-activated protein kinase in adipose tissue. $J$ Physiol 574: 5562, 2006.

DEEPA SS, DONG LQ: APPL1: role in adiponectin signaling and beyond. Am J Physiol Endocrinol Metab 296: E22E36, 2009.

DIAZ-GUERRA MJ, JUNCO M, BOSCA L: Oleic acid promotes changes in the subcellular distribution of protein kinase C in isolated hepatocytes. $J$ Biol Chem 266: 23568-23576, 1991.

FASSHAUER M, KLEIN J, KRALISCH S, KLIER M, LOSSNER U, BLUHER M, PASCHKE R: Growth hormone is a positive regulator of adiponectin receptor 2 in 3T3-L1 adipocytes. FEBS Lett 558: 27-32, 2004.

FRAYN KN: Adipose tissue and the insulin resistance syndrome. Proc Nutr Soc 60: 375-380, 2001.

GAO Y, ZHOU Y, XU A, WU D: Effects of an AMP-activated protein kinase inhibitor, compound C, on adipogenic differentiation of 3T3-L1 cells. Biol Pharm Bull 31: 1716-1722, 2008.

GARTON AJ, CAMPBELL DG, CARLING D, HARDIE DG, COLBRAN RJ, YEAMAN SJ: Phosphorylation of bovine hormone-sensitive lipase by the AMP-activated protein kinase. A possible antilipolytic mechanism. Eur J Biochem 179: 249-254, 1989.

GARTON AJ, YEAMAN SJ: Identification and role of the basal phosphorylation site on hormone-sensitive lipase. Eur J Biochem 191: 245-250, 1990.

HALUZIK M, PARIZKOVA J, HALUZIK MM: Adiponectin and its role in the obesity-induced insulin resistance and related complications. Minireview. Physiol Res 53: 123-129, 2004. 
VAN HARMELEN V, LONNQVIST F, THORNE A, WENNLUND A, LARGE V, REYNISDOTTIR S, ARNER P: Noradrenaline-induced lipolysis in isolated mesenteric, omental and subcutaneous adipocytes from obese subjects. Int J Obes 21: 972-979, 1997.

HAYES C, KRISKA A: Role of physical activity in diabetes management and prevention. J Am Diet Assoc 108: S19$\mathrm{S} 23,2008$.

HOFFSTEDT J, ARNER P, HELLERS G, LONNQVIST F: Variation in adrenergic regulation of lipolysis between omental and subcutaneous adipocytes from obese and non-obese men. J Lipid Res 38: 795-804, 1997.

HOJLUND K, MUSTARD KJ, STAEHR P, HARDIE DG, BECK-NIELSEN H, RICHTER EA, WOJTASZEWSKI JF: AMPK activity and isoform protein expression are similar in muscle of obese subjects with and without type 2 diabetes. Am J Physiol Endocrinol Metab 286: E239-E244, 2004.

HOLM C: Molecular mechanisms regulating hormone-sensitive lipase and lipolysis. Biochem Soc Trans 31: 1120-1124, 2003.

JOCKEN JW, SMIT E, GOOSSENS GH, ESSERS YP, VAN BAAK MA, MENSINK M, SARIS WH, BLAAK EE: Adipose triglyceride lipase (ATGL) expression in human skeletal muscle is type I (oxidative) fiber specific. Histochem Cell Biol 129: 535-538, 2008.

KADOWAKI T, YAMAUCHI T, KUBOTA N, HARA K, UEKI K, TOBE K: Adiponectin and adiponectin receptors in insulin resistance, diabetes, and the metabolic syndrome. J Clin Invest 116: 1784-1792, 2006.

KOH HJ, HIRSHMAN MF, HE H, LI Y, MANABE Y, BALSCHI JA, GOODYEAR LJ: Adrenaline is a critical mediator of acute exercise-induced AMP-activated protein kinase activation in adipocytes. Biochem $J$ 403: 473-481, 2007.

KOLEHMAINEN M, OHISALO JJ, KAARTINEN JM, TUONONEN V, PAAKKONEN M, POIKOLAINEN E, ALHAVA E, UUSITUPA MI: Concordance of in vivo microdialysis and in vitro techniques in the studies of adipose tissue metabolism. Int J Obes Relat Metab Disord 24: 1426-1432, 2000.

LAESSLE RG, WURMSER H, PIRKE KM: A comparison of resting metabolic rate, self-rated food intake, growth hormone, and insulin levels in obese and nonobese preadolescents. Physiol Behav 61: 725-729, 1997.

LAFONTAN M, MORO C, BERLAN M, CRAMPES F, SENGENES C, GALITZKY J: Control of lipolysis by natriuretic peptides and cyclic GMP. Trends Endocrinol Metab 19: 130-137, 2008.

LANGIN D, DICKER A, TAVERNIER G, HOFFSTEDT J, MAIRAL A, RYDEN M, ARNER E, SICARD A, JENKINS CM, VIGUERIE N, VAN HERMELEN V, GROSS RW, HOLM C, ARNER P: Adipocyte lipases and defect of lipolysis in human obesity. Diabetes 54: 3190-3197, 2005.

LARGE V, ARNER P: Regulation of lipolysis in humans. Pathophysiological modulation in obesity, diabetes, and hyperlipidaemia. Diabetes Metab 24: 409-418, 1998.

LUNDGREN M, BUREN J, LINDGREN P, MYRNAS T, RUGE T, ERIKSSON JW: Sex- and depot-specific lipolysis regulation in human adipocytes: interplay between adrenergic stimulation and glucocorticoids. Horm Metab Res 40: 854-860, 2008.

MAO X, KIKANI CK, RIOJAS RA, LANGLAIS P, WANG L, RAMOS FJ, FANG Q, CHRIST-ROBERTS CY, HONG JY, KIM RY, LIU F, DONG LQ: APPL1 binds to adiponectin receptors and mediates adiponectin signalling and function. Nat Cell Biol 8: 516-523, 2006.

MAURIEGE P, IMBEAULT P, LANGIN D, LACAILLE M, ALMERAS N, TREMBLAY A, DESPRES JP: Regional and gender variations in adipose tissue lipolysis in response to weight loss. J Lipid Res 40: 1559-1571, 1999.

MITSUUCHI Y, JOHNSON SW, SONODA G, TANNO S, GOLEMIS EA, TESTA JR: Identification of a chromosome 3p14.3-21.1 gene, APPL, encoding an adaptor molecule that interacts with the oncoproteinserine/threonine kinase AKT2. Oncogene 18: 4891-4898, 1999.

MOLLER N, JORGENSEN JO: Effects of growth hormone on glucose, lipid, and protein metabolism in human subjects. Endocrine reviews 30: 152-177, 2009.

MULLEN KL, PRITCHARD J, RITCHIE I, SNOOK LA, CHABOWSKI A, BONEN A, WRIGHT D, DYCK DJ: Adiponectin resistance precedes the accumulation of skeletal muscle lipids and insulin resistance in high-fatfed rats. Am J Physiol Regul Integr Comp Physiol 296: R243-R251, 2009.

NEDVIDKOVA J, SMITKA K, KOPSKY V, HAINER V: Adiponectin, an adipocyte-derived protein. Minireview. Physiol Res 54: 133-140, 2005. 
PAOLISSO G, GAMBARDELLA A, AMATO L, TORTORIELLO R, D'AMORE A, VARRICCHIO M, D'ONORFIO F: Opposite effects of short- and long-term fatty acid infusion on insulin secretion in healthy subjects. Diabetologia 38: 1295-1299, 1995.

POLAK J, MORO C, BESSIERE D, HEJNOVA J, MARQUES MA, BAJZOVA M, LAFONTAN M, CRAMPES F, BERLAN M, STICH V: Acute exposure to long-chain fatty acids impairs $\alpha_{2}$-adrenergic receptor-mediated antilipolysis in human adipose tissue. J Lipid Res 48: 2236-2246, 2007.

QVISTH V, HAGSTROM-TOFT E, ENOKSSON S, MOBERG E, ARNER P, BOLINDER J: Human skeletal muscle lipolysis is more responsive to epinephrine than to norepinephrine stimulation in vivo. $J$ Clin Endocrinol Metab 91: 665-670, 2006.

RANDLE PJ.: Regulatory interactions between lipids and carbohydrates: the glucose fatty acid cycle after 35 years. Diabetes Metab Rev 14: 263-283, 1998.

RODBELL M: Metabolism of isolated fat cells. I. Effects of hormones on glucose metabolism and lipolysis. $J$ Biol Chem 239: 375-380, 1964.

SAITO T, JONES CC, HUANG S, CZECH MP, PILCH PF: The interaction of Akt with APPL1 is required for insulinstimulated Glut4 translocation. J Biol Chem 282: 32280-32287, 2007.

STAIGER H, KALTENBACH S, STAIGER K, STEFAN N, FRITSCHE A, GUIRGUIS A, PETERFI C, WEISSER M, MACHICAO F, STUMVOLL M, HARING HU: Expression of adiponectin receptor mRNA in human skeletal muscle cells is related to in vivo parameters of glucose and lipid metabolism. Diabetes $\mathbf{5 3}$ : 2195-2201, 2004.

STEINBERG GR, SMITH AC, VAN DENDEREN BJ, CHEN Z, MURTHY S, CAMPBELL DJ, HEIGENHAUSER GJ, DYCK DJ, KEMP BE: AMP-activated protein kinase is not down-regulated in human skeletal muscle of obese females. J Clin Endocrinol Metab 89: 4575-4580, 2004.

STICH V, PELIKANOVA T, WOHL P, SENGENES C, ZAKAROFF-GIRARD A, LAFONTAN M, BERLAN M: Activation of alpha2-adrenergic receptors blunts epinephrine-induced lipolysis in subcutaneous adipose tissue during a hyperinsulinemic euglycemic clamp in men. Am J Physiol Endocrinol Metab 285: E599-E607, 2003.

TAN BK, CHEN J, DIGBY JE, KEAY SD, KENNEDY CR, RANDEVA HS: Upregulation of adiponectin receptor 1 and 2 mRNA and protein in adipose tissue and adipocytes in insulin-resistant women with polycystic ovary syndrome. Diabetologia 49: 2723-2728, 2006.

TSUCHIDA A, YAMAUCHI T, ITO Y, HADA Y, MAKI T, TAKEKAWA S, KAMON J, KOBAYASHI M, SUZUKI R, HARA K, KUBOTA N, TERAUCHI Y, FROGUEL P, NAKAE J, KASUGA M, ACCILI D, TOBE K, UEKI K, NAGAI R, KADOWAKI T: Insulin/Foxo1 pathway regulates expression levels of adiponectin receptors and adiponectin sensitivity. J Biol Chem 279: 30817-30822, 2004.

VELDHUIS JD, IRANMANESH A, HO KK, WATERS MJ, JOHNSON ML, LIZARRALDE G: Dual defects in pulsatile growth hormone secretion and clearance subserve the hyposomatotropism of obesity in man. $J$ Clin Endocrinol Metab 72: 51-59, 1991.

YAMAUCHI T, KAMON J, ITO Y, TSUCHIDA A, YOKOMIZO T, KITA S, SUGIYAMA T, MIYAGISHI M, HARA K, TSUNODA M, MURAKAMI K, OHTEKI T, UCHIDA S, TAKEKAWA S, WAKI H, TSUNO NH, SHIBATA Y, TERAUCHI Y, FROGUEL P, TOBE K, KOYASU S, TAIRA K, KITAMURA T, SHIMIZU T, NAGAI R, KADOWAKI T: Cloning of adiponectin receptors that mediate antidiabetic metabolic effects. Nature 423: 762-769, 2003.

YAMAUCHI T, KAMON J, MINOKOSHI Y, ITO Y, WAKI H, UCHIDA S, YAMASHITA S, NODA M, KITA S, UEKI K, ETO K, AKANUMA Y, FROGUEL P, FOUFELLE F, FERRE P, CARLING D, KIMURA S, NAGAI R, KAHN BB, KADOWAKI T: Adiponectin stimulates glucose utilization and fatty-acid oxidation by activating AMP-activated protein kinase. Nat Med 8: 1288-1295, 2002.

YANEY GC, KORCHAK HM, CORKEY BE: Long-chain acyl CoA regulation of protein kinase C and fatty acid potentiation of glucose-stimulated insulin secretion in clonal beta-cells. Endocrinology 141: 1989-1998, 2000.

YANG L, LIN HK, ALTUWAIJRI S, XIE S, WANG L, CHANG C: APPL suppresses androgen receptor transactivation via potentiating Akt activity. J Biol Chem 278: 16820-16827, 2003. 
ZHOU G, MYERS R, LI Y, CHEN Y, SHEN X, FENYK-MELODY J, WU M, VENTRE J, DOEBBER T, FUJII N, MUSI N, HIRSHMAN MF, GOODYEAR LJ, MOLLER DE: Role of AMP-activated protein kinase in mechanism of metformin action. J Clin Invest 108: 1167-1174, 2001. 